\title{
JAN TRYNKOWSKI
}

\section{JAN WOLSKI I JEGO AUTOBIOGRAFIA}

Jan Wolski to wieloletni i ogromnie zasłużony nauczyciel Gimnazjum Białostockiego. Jego biografia nie jest nam dobrze znana i skazani jesteśmy na mozolną jej rekonstrukcję.

Urodził się w 1781 r. w powiecie brzeskim jako syn Stanisława. Uczył się w Brześciu Litewskim w bazyliańskiej szkole powiatowej (patent uzyskał dn. 30.VII. 1802 r.) i rok jeden w takiejże szkole w Żyrowicach (pow. słonimski)리 w której otrzymał świadectwo dn. 30. VI. 1803 r. by następnie wstąpić na Uniwersytet Wileński gdzie studiował na Wydziale Nauk Fizyczno-Matematycznych. W czasie studiów zaprzyjaźnił się z Antonim Suchodolskim. Obaj zostali wyróżnieni w 1805 r. nagrodą pieniężną przyznawaną wybijającym się studentom ${ }^{2}$. Po ukończeniu studiów, w stopniu magistra filozofii, podejmuje pracę nauczyciela fizyki i historii naturalnej w gimnazjum w Świsłoczy (tam też pracuje A. Suchodolski), gdzie zasłynął jako znakomity pedagog ${ }^{3}$. Wspominał go ciepło po latach uczeń gimnazjum świsłockiego, a później znany publicysta i krytyk literacki, Leon Zienkowicz, który pisał o Wolskim: mąz światty i zacny ... odbierał ciagle dowody mitości i szacunku mlodzieży $y^{4}$. Pełnił też w Świsłoczy przez trzy lata funkcje pomocnika dyrektora gimnazjum (czyli ... A. Suchodolskiego). Tu powstały jego pierwsze drukowane prace. Pierwszą z nich była drukowana w Wilnie w 1808 r. Rozprawa o czlowieku czytana przy zaczęciu się Szkót Gimnazjum Grodzieńskiego w Świstoczy w roku 1808 dnia 15 septembra przez Jana Wolskiego w tychże szkolach nauczyciela fizyki. Ta dedykowana założycielowi i fundatorowi gimnazjum w Świsłoczy (w 1806 r.) Wincentemu Tyszkiewiczowi broszura jest skróconym tłumaczeniem pierwszego rozdziału, zaledwie kilka lat wcześniej wydanej w Paryżu

\footnotetext{
' Powiatowa szkoła szlachecka w Żyrowicach, od 1795 r. prowadzona była przez bazylianów. L. Zasztowt, Kresy 1832 - 1864. Szkolnictwo na ziemiach litewskich $i$ ruskich dawnej Rzeczypospolitej, Warszawa 1997 , s. 178.

${ }^{2}$ J. Bieliński, Uniwersytet Wileński: 1579-1831, Kraków 1899-1900, t. 2 s. 780; Ten znakomity znawca dziejów Uniwersytetu Wileńskiego i losów jego wychowanków, w innym miejscu swego monumentalnego dzieła, pisząc o Janie Wolskim, lakonicznie stwierdza: Biegu jego życia nie znamy, op. cit. t. III s. 492.

${ }^{3}$ L. Janowski, Slownik bio - bibliograficzny dawnego Uniwersytetu Wileńskiego, Wilno 1939, s. 497: Slawny nauczyciel.

${ }^{4}$ L. Zienkowicz, Wieczory Lacha z Lachów, czyli opowiadania przy kominku starego Literata polskiego. Lipsk 1864, s. 154-155.

${ }^{5}$ A. J. J. Virey, Histoire naturelle de l'homme, Paris 1801. Książka ta w tłumaczeniu na język polski ukazała się w Warszawie dopiero w 1843 r. (Historia naturalna rodu ludzkiego, w czterech tomach).
} 
rozprawy A. Virey'as a jednocześnie dowodem szerokich horyzontów myślowych Wolskiego ${ }^{6}$. W dziesięć lat później przygotował i wydał podręcznik fizyki: Fizyka stosownie do teraźniejszego stanu wiadomości krótko zebrana przez Jana Wolskiego magistra filozofii, nauczyciela fizyki i historii naturalnej w gimnazjum świstockim, guberni grodzieńskiej, pomocnika dyrektora, chcącym się obeznać z pierwszymi zasadami tej nauki, pożytecznie stużyć mogqca. Warszawa 1818. W 1824 r. Jan Wolski (razem z A. Suchodolskim) rozpoczyna pracę w gimnazjum w Białymstoku jako nauczyciel fizyki i historii naturalnej’. Już rok później, 22 maja 1825 r. dyrektor Antoni Suchodolski w raporcie dla wizytującego gimnazjum prof. K Podczaszyńskiego taką mu wystawia opinię: Nauczyciel fizyki, magister filozofii, kollegialny assesor p. Jan Wolski kończy stużby swojej lat 18, w ciqgu której zbierajac statecznie wiadomości czyniqce go dobrze usposobionym nauczycielem, dając ciagle dowody gorliwości, zdaje się nabywać prawa do pozyskania względów swej zwierzchności dla osiaggnięcia uyższego szkolnego placu ${ }^{8}$. Nie sposób ocenić obiektywizmu powyższej opinii, wystawionej przecież przez człowieka bardzo blisko z Wolskim związanego. Pewni być możemy, że Wolski i w Białymstoku, podobnie jak w Świsłoczy, „pozyskał wzglẹdy" swych uczniów. Szereg lat później, przebywający na zesłaniu syberyjskim absolwent gimnazjum białostockiego, lekarz Maciej Łowicki ${ }^{9}$ wspominając swych nauczycieli gimnazjalnych, a zwłaszcza tych, którzy jego zdaniem mogliby wykładać na uniwersytecie napisze: Takimże byt nauczycielem stary Wotski Jan, bo przy mnie wystużyt emeryturę. Wykładal on nam najlepiej całq fizykę i historię naturalnq. Wszędzie głęboki moralista i myśliciel, lubiąc po ojcowsku swych uczniów byt szanowany od nich i od swych kolegów mtodszych jak patriarcha szkoty ${ }^{10}$. Z rzewnym ogólnym placzem żegnaliśmy jego. Plakat $i$ on sam jak prawdziwy ojciec rozstając się $z$ dziećmi. Pamiętam na ostatniej lekcji wytożyt nam teorię piorunów i gradu i odzywając się do majętniejszych uczniów, synów obywatelskich, zalecat im szczególnie zwrócić braterskie serce na swoich wtościan, dać im poczuć, że oni sq ludźmi i takim sposobem tylko starać się zjednywać ich przychylnq ustuge dla siebie. Zastugiwat on być profesorem a nie nauczycielem. Powazna, ptynna wymowa jego zdobita. On byt najzdolniejszym rozwijać mlodzieńcze umysty ${ }^{11}$. Trudno o piękniejszą nagrodę za nauczycielskie trudy,

${ }^{6} \mathrm{~J}$. Mydlarski, Obudzenie zainteresowań antropologiq przez ośrodek wileński na przełomie wieku XVIII $i$ XIX. Przegląd Antropologiczny, t. XVIII 1952, s. 286 - 288; Tłumaczenie kolejnych części dzieła Virey'a publikował Wolski w „Pamiętniku Magnetycznym Wileńskim”, O poczq̨tkouym nastaniu wszystkich istot stworzonych, t.1 (1816), s. 84-104; t. 2 (1817), s.361-372; t. 3 (1818), nr 9, s.56 -58, nr 11, s. $33-52$.

${ }^{7}$ Archiwum PAN - Warszawa III-76. Materiały Ludwika Chmaja. 92: Szkoty średnie i niższe w okręgu naukouym wilerískim, k. 18.

${ }^{8}$ Rkps Bibl. Jagiell. 6335 IV k. 48 (Materiaty dotyczące wizytacji szkól Wydzialu Wileńskiego, przeprowadzonej przez Karola Podczaszyńskiego w 1825 r.).

${ }^{9}$ J. Szumski, M. Łowicki (1816 - 1900). Dzieciństwo i lata szkolne, „Białostocczyzna” 1987, nr 4, s. 14-19; J. Trynkowski, Maciej Łowicki i jego „Lekarsko - praktyczne notatki” [w:] Syberia w historii $i$ kulturze narodu polskiego, Warszawa 1998, s. 136 - 144.

${ }^{10}$ To podkreślanie podeszłego wieku Wolskiego jest zastanawiające, Łowicki ukończył Gimnazjum w Białymstoku w 1834 r., gdy Wolski miał lat 54. Być może Łowicki zapamiętał powszechny szacunek jakim się cieszył Wolski, jego autorytet i stąd we wspomnieniach pisanych 20 lat później obraz starego człowieka.

$"$ M. Łowicki (= Adolf spod Bielska). Gawęda krytyko-literacka nr 9. Pan Tomasz wspomina swych nauczycieli w Bialymstoku (5 XII 1850), Rkps Bibl. Nar. II 7836; J: Trynkowski, Wspomnienie Macieja Łowickiego o nauczycielach gimnazjum bialostockiego, „Białostocczyzna” 1998/ 3 (51), s. 14-24. 
jak taka pochwała ze strony uczniów, sformułowana po latach, a więc bezinteresowna. Ale na nagrodę taką trzeba zasłużyć.

Gdy 5 października 1827 r w okolicach Białegostoku spadł deszcz meteorytów, Wolski niemal natychmiast udał się do Fast, gdzie rzadkie to zjawisko zaobserwowano i osobiście, przy pomocy swoich uczniów z gimnazjum, rzecz całą skrupulatnie zbadał i sporządził raport przesłany władzom Uniwersytetu Wileńskiego. Raport ten w sposób rzetelny a jednocześnie barwny opisujący to niecodzienne wydarzenie został opublikowany w ówczesnej prasie wileńskiej ${ }^{12}$, a i później był przypominany ${ }^{13}$. Warto tu powiedzieć, że dzięki Wolskiemu meteoryt „Białystok” jest najstarszym „polskim” meteorytem, okoliczności upadku którego dokładnie i „na gorąco" odnotowano.

Mówiąc o białostockim okresie życia J. Wolskiego, trzeba koniecznie wspomnieć o nigdy niepublikowanej jego pracy, która powinna zainteresować ekologów - mowa o znajdującym się kiedyś w bibliotece Kijowskiego Towarzystwa Przyrodniczego (a obecnie w Archiwum Biblioteki Akademii Nauk w Kijowie ${ }^{14}$ ) rękopisie przesłanym ówczesnemu profesorowi Uniwersytetu Kijowskiego, znanemu botanikowi związanemu z Wilnem i Krzemieńcem, W. Besserowi. Jest to Katalog roślin zebranych z okolic bliskich obwodowego miasta Białegostoku, z lat 1827 - 1829, obejmujący 743 gatunki ${ }^{15}$. W latach następnych Wolski kontynuował zbieranie roślin powiększając swój katalog do 919 gatunków ${ }^{16}$. Byłoby interesujące stwierdzić dzisiaj, jak wielkie zmiany od tego czasu zaszły we florze okolic Białegostoku.

Na początku 1833 r., po 25 latach pracy w zawodzie nauczycielskim, w randze nadwornego radcy zostaje odesłany na emeryturę, mimo starań jego samego i dyr. gimnazjum A. Powstańskiego o umożliwienie mu dalszej pracy. Jeszcze w czerwcu tegoż roku dyr. A. Powstański rekomenduje go na stanowisko kierownika projektowanej biblioteki publicznej w Białymstoku ${ }^{17}$. Do powstania takiej biblioteki nie doszło i Wolski ani tej ani innej pracy już nie otrzymał.

Wiemy, że Jan Wolski był żonaty (od 1808 r.) z Józefą z Grzymałów, córką majora wojsk rosyjskich, że miał czworo dzieci, które w 1821 roku miały: Edward lat 10, Julia lat 11, Pelagia lat $9 \mathrm{i}$ Idalia lat $3^{18}$. Umarł mając lat 70, w Białymstoku dn. 24 lipca 1850 r. $^{19}$ Żona jego otrzymała po nim dożywotnią emeryturę w pełnej wysokości (400 r.sr. rocznie) ${ }^{20}$.

Zarówno jego biografia, jak i dorobek (tak drukowany, jak i rękopiśmienny), zasługują na szczegółowe opracowanie.

12 O spadnieniu kamieni z powietrza pod Bialymstokiem, we wsi Fastach, „Dziennik Wileński” 1827, Um. i Szt. t. II, s. 391-395 (= „Kurier Litewski” 21 października 1827).

${ }^{13}$ B. Olendzka [w:] „Wiadomości Muzeum Ziemi” 1939, nr 1/2, s. 65-67 ( z niewielkimi skrótami); J. Trynkowski, Meteoryt bialostocki, „Białostocczyzna” 1997, nr 3 (47), s. 6-13.

${ }^{14}$ BAN Ukr. Zesp. I 1420, Ad floram; W. Grębecka, Wilno - Krzemieniec. Botaniczna szkola naukowa (1781-1841). Warszawa 1998, s. 135.

19.

${ }^{16}$ LVIA (Wilno), Zesp. 567, inw. 2, vol. 3060, k. 12-13. (Continuatio indicis plantarum locis Bialistociae..).

${ }^{17}$ NGAB (Grodno), Zesp. 1, inw.20, vol. 1636.

${ }^{18}$ Archiwum PAN - Warszawa III-76, Materiały L. Chmaja 94: Nauczyciele, pracownicy nauki oraz oświaty w okręgu naukouym wileńskim ok. 1825 r., k. 478.

${ }^{19}$ Słownik Biologów Polskich, Warszawa 1987, s. 585-586 (Barbara Zielińska).

20 LVIA (Wilno), Zesp. 567, inw. 2, vol. 6398. 
W Archiwum Głównym Akt Dawnych udało się odszukać własnoręcznie pisaną biografię Jana Wolskiego. Dokument ten zarówno ze względu na osobę tego godnego uwagi nauczyciela Gimnazjum Białostockiego, jak i interesującą treść, zasługuje na publikację i niezbędny komentarz. Teki Hipolita Skimborowicza $a^{21}$, zespół w którym znajduje się Autobiografia Wolskiego, dostarcza nam informacji pozwalających poznać przyczyny i okoliczności powstania tego tekstu. Najważniejszy jest tu niewątpliwie list Ignacego Kułakowskiego ${ }^{22}$ pisany do H. Skimborowicza z Białegostoku dn. 24 sierpnia (v.s.) 1848 r. ${ }^{23} \mathrm{~W}$ liście tym Kułakowski tłumaczy się z okoliczności, które spowodowały, że dopiero teraz odpowiada na listy z 1 czerwca i 4 września 1847 r. (może już mnie do pocztu owych zaliczyleś ludzi co to bądź z nieużycia, bądź z opieszałości milczq upornie), wyjaśnia, że zebranie informacji o które Skimborowicz prosił zajęło mu dużo czasu: szło mi bardzo opieszale, często niezależnie od mojej woli i chęci zbieranie wiadomości potrzebnych, które tu i ówdzie zagrzęzly jak w sqsiedztwie blotnistym Polesia. Następuje szereg szczegółowych odpowiedzi na zadane pytania (większość to informacje typu bibliograficznego) a wśród nich, to co nas najbardziej interesuje - wyliczenie tekstów, które przesyła w załączeniu: O Chromińskim: Notatka Wolskiego, takażZdanowskiego, wypis z archiwum grodzieńskiego gimnazjum .... Autobiografia Wolskiego i notatka o Wolskim zięcia jego Zdanowskiego.

Jak się wydaje H. Skimborowicz zwrócił się do I. Kołakowskiego o informacje o interesujących go osobach w związku z prowadzoną przez siebie przez wiele lat pracą nad Stownikiem pisarzy $i$ artystów polskich, którego rękopis (w siedmiu tomach), przechowywany w bibliotece Przeździeckich, uległ zniszczeniu w 1944 r. Z przesłanych przez Kołakowskiego tekstów większość udało się odszukać. Z materiałów dotyczących Kazimierza Chromińskiego ${ }^{24}$ zachował się Życiorys Chromińskiego Kazimierza, pióra J. Wolskiego ${ }^{2.5}$, notatka Zdanowskiego i wypis z archiwum dyrekcji szkół gub. grodzieńskiej²6.

Niestety nie udało się odszukać wspomnianej w liście Kołakowskiego notatki o Wolskim, zięcia jego Zdanowskiego ${ }^{27}$. Wielka to szkoda, sądzić bowiem należy, że notatka ta zawierała

${ }^{21}$ Hipolit Skimborowicz (1815-1880), zasłużony publicysta, działacz konspiracyjny i redaktor szeregu czasopism - m. in. „Przeglądu Naukowego” (Warszawa 1842-1848). Zob. Bibliografia Literatury Polskiej, t.9, s. 144-147, 541 .

${ }^{22}$ Ignacy Kułakowski (1800-1860), dyrektor gimnazjum w Białymstoku (1843-1860), poeta, historyk - amator. PSB, t. 13, s.330-331(Z. Makowiecka); R. Gerber, Studenci Uniwersytetu Warszawskiego 18081831. Stownik biograficzny, Wrocław 1977, s.96; ks. J. Sochoń, Ignacy Kulakowski-zapomniany poeta i pedagog, „Białostocki Informator Kulturalny” 1979 maj, s. 16-20; W. A. Djakow i in., Uczestnicy ruchów wolnościouych w latach1832 -1855 (Królestwo Polskie). Przewodnik biograficzny, Wrocław 1990, s. 229.

${ }^{23}$ AGAD, Teki H.Skimborowicza, XXV 171, k. 1-2.

${ }^{24}$ Kazimierz Chromiński (1759-1816), nauczyciel, historyk literatury. Uczył w gimnazjum w Świsłoczy w latach 1807 - 1816, wtedy go poznał J. Wolski. W 1815 r. przedłożył na Uniwesytecie Wileńskim rozprawę doktorską O literaturze polskiej wieku XVIII. Gromadził książki i ryciny, pracował nad słownikiem pisarzy polskich.

25 AGAD, Teki H. Skimborowicza, XXIV 2/25.

${ }^{26}$ tamże, XXIII 1/47: Chromiński: wiadomości o jego życiu.

${ }^{27}$ Zdanowski Piotr, ur. ok. 1800 r., syn Jana - ukończył gimnazjum wileńskie, a następnie Uniwersytet Wileński, uzyskując stopień kandydata filozofii (26 VI 1819 r.). Czas jakiś pracował jako nauczyciel prywatny. 26 II 1829 otrzymał nominację do gimnazjum w Białymstoku, gdzie był nauczycielem łaciny. Wiemy o nim mało, nie wiemy, z którą z córek Wolskiego się ożenił i kiedy. 
wiele szczegółów z biografii Wolskiego, szczegółów dziś nam nieznanych. Szczęśliwie zachowała się publikowana niżej Autobiografia J. Wolskiego ${ }^{28}$.

Tekst ten jest do pewnego stopnia rozczarowujący, nie dowiadujemy się z niego szeregu ważnych informacji o jego życiu. Nie wiemy gdzie się urodził, kim byli jego rodzice, gdzie pobierał nauki początkowe. Nie wspomina, że po nauce w szkole Brześciu, uczył się jeszcze w Żyrowicach. I czego nie sposób wytłumaczyć, nic nie pisze o białostockim okresie swego życia, gdzie przecież pracował lat 10 i gdzie mieszkał stale, będąc już na emeryturze. Nie umiemy wytłumaczyć dlaczego pisze, że przeszedł na emeryturę w randze radcy kolegialnego, gdy pewni jesteśmy, że był wtedy w randze nadwornego radcy... Takich „braków” jest w Autobiografii więcej. Być może J. Wolski o takich szczegółach nie pisał świadomie, wiedząc, że napisze o tym jego zięć P. Zdanowski?

Autobiografia jest jednocześnie tekstem ogromnie interesującym może właśnie dlatego, że jej autor nie tyle rozpisuje się o szczegółach swego życia, ile dokonuje swoistego rozrachunku ze swojej drogi życiowej, spoglądając na nią z perspektywy swych 65 lat. Wolski uczył się w okresie, kiedy w sposobach nauczania, w całym systemie oświatowym dokonywały się rewolucyjne wręcz zmiany. Zaczynał, gdy jeszcze obowiązywały stare podręczniki, gdy podstawą nauki było „wkuwanie” na pamięć, gdy właściwie nie trzeba było niczego rozumieć, a ostatecznym autorytetem był nauczyciel i jego słowa. Od takiej „jezuickiej” szkoły, poprzez szkołę „pijarską”, przeszedł (a właściwie to ona do niego „przyszła”), do szkoły ogromnie nowoczesnej, wykorzystującej najnowsze zdobycze nauki i myśli oświeceniowej - szkoły jaką Rzeczpospolita zawdzięczała twórcom Komisji Edukacji Narodowej. Jakież szczególne znaczenie mają słowa tego człowieka, który doświadczył tego chaosu przemian jako uczeń, dziecko jeszcze, a po latach z perspektywy swego doświadczenia pedagogicznego stwierdzi: otworzyty nam się oczy, żeśmy podtug starej metody wiele czasu stracili na ćwiczenie samej pamięci, mato użytecznymi erudycjami i nieodżatowana byla szkoda, ześmy tak od początków nie zaczęli...

Autobiografia Wolskiego powinna zainteresować nie tylko historyków oświaty. Są tu zawarte poglądy autora na szereg spraw najróżniejszych: wychowania dzieci (i roli jaką ma tu do spełnienia rodzina), stanu rolnictwa krajowego i sposobów jego poprawy, rozważania czym jest dobro ogólne, myśli o społecznym znaczeniu nauki, potrzebie szerzenia oświaty pozaszkolnej ... Wszystko to stanowi kapitalne źródło wiedzy o sposobie widzenia świata, myślenia i ogólnie rzecz biorąc, postawy tego przedstawiciela rodzącej się inteligencji polskiej, a ściśle rzecz biorąc - podlaskiej, o której w okresie o którym mowa (pierwsza poł. XIX w.) wiemy ciągle zbyt mało.

28 AGAD, Teki H. Skimborowicza, XXIV 2/24, k. 1-4. 


\section{BIOGRAFIA}

Przeżyłem lat 60 - rok 1847 jest 65 rokiem życia mojego. Wchodzę w period starości, zgrzybiałości nie pragnę, niezadługo żyć przestanę - musiało to być z rozrządzenia wyższego, musiało to być potrzebnym. Ciąży przeto na mnie obowiązek abym się obrachował ile odpowiedziałem zamiarom przyrodzenia przez pożyteczne życie w społeczności do której przeznaczony zostałem; niniejsze pismo ma to okazać.

Wiek dziecinny Od momentu przyjścia na świat, dzieci tym są do siebie podobne, że przestają na pokarmie jaki przyrodzenie w łonie matki przygotowało; tworzą się w nich i rozwijają organa potrzebne do przyszłego życia. Organa te są narzędziami przymiotów - a przymiotami duszy i ciała człowiek ma być użytecznym. Matko! najgodniejszy dla niewiasty tytule!, na ciebie chcę zwrócić uwagę, tobie przypomnieć, że od momentu w jakim być nią zaczęłaś i natura i obowiązki stanu twego ostrzegają abyś cała poświęciła się na wydanie na świat i wypielęgnowanie twojego dziecięcia. Cierpienia jakich możesz doświadczać w tym periodzie dowodzą, że przyrodzenie kosztem twoim wydaje potomka; miejże na uwadze skarb ten w łonie twoim złożony, dogadzaj jemu i przygotuj się do nowych zatrudnień, trosków i starań. Pierwszy głos jaki usłyszysz po przyjściu na świat, będzie to głos wzywający twojej pomocy, starania i trudów macierzyńskich, abyś za nie z czasem miała pociechę serca, droższą nad wszystkie inne. Pomnij, że cię oczekuje podwójna chwała: raz, że uiścisz się z długu rodzicom za ich około ciebie starania; drugi, że masz dostarczyć pożądanego członka społeczności. Zacznij więc swoje starania od tego abyś wypielęgnowała niemowlę zdrowo i czysto; przerwij twoje zabawy, które tylko ciebie zajmowały, a od momentu rozwijania się w nim zdolności umysłowych, czuwaj ciągle nad ich prostowaniem i kształceniem. Pomnij, że nie masz szczęścia większego dla matki, jak mieć dobre dzieci i większego nieszczęścia, jak złe - a to wszystko od początkowych wrażeń i starań zależy. Ja nie miałem tego szczęścia, bo chorowita moja matka samym tylko cierpieniem była zajęta. To tylko pamiętam, że gdy po kilku latach byłem w stanie wpatrywać się w jej położenie i dzielić jej cierpienia, ukształciłem serce czułe, przymiot w mężczyznach nawet chwalebny, bo usposabia do dzielenia niedoli i wsparcia w miarę możności, cierpiących osób, cierpiącej ludzkości.

W dziecku od momentu poczynającego się poznawania, jest dążenie do złego i dobrego, bo taka natura ludzka; to też w każdym czasie bez względu na ich wiek niemowlęcy lub dziecinny uwagę na to zwracać należy. Za ogólną zasadę postępowania rodzicielskiego mieć należy: aby dbać a nie pobłażać, czuwać a nie zaniedbywać, kochać rozsądnie a nie rozpieszczać dzieci. Poczciwa matko, zapłacz w kącie, żeś dziecko ukarała, ale w oczy nie daj poznać, aby nie było winne wtenczas, kiedy coś złego na nim dostrzegła. Niech wola twoja będzie jego wolą, niech będzie twoim niewolnikiem, niech pełni od razu twoje rozkazy, niech ciebie się radzi i słucha, bo posłuszeństwo dziecka zastąpi jego rozsądek, który dopiero z czasem i po długim doświadczeniu się nabywa. Jestem naturalistą bez uprzedzenia, nie przypuszczam aby niektóre dzieci z natury były całkowicie złymi - są one wprawdzie na wszystko obojętne, a skierowanie początkowe może im tylko nadać wartość osobistą i towarzyską. 
Nie idzie zatem aby dzieci nie były dziećmi, chcę mówić aby wszystkie ich kroki odznaczały się tą surowością obyczajów, jakiej się od dojrzalszych ludzi wymaga: owszem, ruch, bieganie, swawola dziecinna, powinny być dzieci żywiołem - bo to wzmacnia ich siły fizyczne, ale się mówi tylko aby ich żywość nie zamieniła się w roztrzepanie, swawola w rozpustę. Nieruchawe dziecko i gnuśne dowodzi, że jest chorowite, wielką zaś wadą będzie rodziców, jeżeli surowe obchodzenie się przytłumi w nich żywość naturalną. Taką koleją dzieci przejdą pierwszy ich period życia; jeżeli albo mało co, albo jeszcze nic nie umieją, mają przynajmniej niezepsute serce i są usposobione do przyjęcia dalszych starań, jakie w córkach od lat 8 a na synach od lat 10 przedsięwziąć należy.

Co do mnie, taką przypominam rozmowę ojca mojego, bo już matki nie miałem. Synu! Zatrudniony domowym staraniem, choćbym chciał czegoś ciebie nauczyć, czas mi nie pozwala, trzeba żebym cię wysłał do szkół - tam uczyć się będziesz jak masz żyć i nabywać wiadomości, abyś sobie i mnie jeżeli Bóg pozwoli na starość i innym był użyteczny. Nie przepisuję tobie czego się masz uczyć; w szkole o tym się dowiesz, ja ci tylko przykazuję, abyś uczył się wszystkiego, czego ciebie uczyć będą. Uchylisz się na jakiś czas z domu, ale ja i ty bądźmy spokojni, gdyż oddaję cię pod dozór i na naukę takich ludzi, którym publiczne wychowanie jest powierzone - słuchaj ich i ucz się. Nie zapominaj tych wszystkich przestróg które ci ś.p. najlepsza twoja matka i ja nieraz udzielaliśmy. Ja cię niekiedy odwiedzać będę, wtenczas opowiesz mi wszystko szczerze i otwarcie czego się dowiesz lub nauczysz. Jak się zasłużysz twoim nauczycielom i o tym powezmę świadectwo, napoisz mnie prawdziwą rozkoszą, w przeciwnym razie zatrujesz moje dni niepokojem i staniesz się niegodnym starań jakie na twoje wygody i wychowanie łożyć muszę. Kiedy wszystko iść będzie dobrze, odwiedzisz czasem twego ojca, a ja cię obsypię błogosławieństwem i prosić będę Pana Boga aby ci dodał sił do kontynuowania twego zawodu. Więcej ci dopiero nie powiem. Gdy Opatrzność dozwoli skończyć ci nauki, pomówimy obszerniej - teraz wybieraj się do szkół. Daj Boże abym cię za każdym widzeniem się tak serdecznie witał, jak cię dopiero wyprawuję. Po takim przemówieniu, rzuciłem się na łono ojca, łzy rzewne mówić mi nie dozwalały i postrzegłem że i mój ojciec równie był rozczulonym.

Wiek młodzieńczy. Pierwsze moje zjawienie się w klasie nabawiło mi kłopotu, bom nie pojmował abym w znacznej liczbie daleko słuszniejszych ode mnie, mógł zająć Profesora uwagę (ex jezuita), ale gdy ten zbliżywszy się, łagodnie do mnie przemówił o celu mego przybycia i oświadczył, że chce wyrozumieć cobym umiał, przyszedłem do siebie i starałem się odzyskać przytomność. Na zapytanie cobym umiał, odpowiedziałem, że nie wiem czy się to może zwać nauką czegom się w domu dowiedział lub nauczył. Czy umiem pacierz? Ja codziennie mówię, bo tak mnie dawniej matka a teraz ojciec przykazywali. Dobrze robisz moje dziecko, wszystko trzeba poczynać od Boga i dla Boga. A jak czytasz? Oto jest książka, przeczytaj - odczytałem kilka wierszy przytomnie i wyraźnie - zdaje się, że to była nauka moralna (Gdy się sparzysz od ognia... $)^{29}$ bom mocno sobie zanotował. Czy umiesz rachować? - tegom się nie uczył, ale zdaje się że umiałem nieraz sobie poradzić gdy szło o jakieś porachunki, odpowiedziawszy przeto na róż-

${ }^{29}$ Antoni Popławski, Moralna nauka dla szkól narodowych na pierwszq i drugq klasę. B.m. 1778; na trzecią klasę. Kraków 1787, podręczniki te miały szereg wydań następnych. Pierwsze słowa tego znakomitego podręcznika na kl. I brzmiały: Gdy się sparzysz od ognia, gdy robiąc co, nożem się skaleczysz, gdy biegajgc upadniesz lub się stluczesz, uważnym i ostrożnym jesteś na drugi raz. Zob. Stanisław Tync, Nauka moralna w szkolach Komisji Edukacji Narodowej, Kraków 1922, szczególnie rozdział VIII: Podręczniki ks. A. Poptawskiego: Moralna nauka na kl. I, II i III, s. 162-230. 
ne zadania posłyszałem od profesora że obeznany jestem $\mathrm{z}$ rozmaitymi działaniami arytmetycznymi, chociaż nie wiedziałem, że się to arytmetyką nazywa. Zadowolony Profesor powiedział mi, że każda nauka ma swoje podziały i prawidła i że należy one poznać, chcąc umieć coś porządnie. Oprócz pacierza czy umiesz co na pamięć? Umiem Pacierz staruszka i kilka bajeczek Krasickiego i śpiewki Karpińskiego. Pacierz staruszka! oto wiersz Naruszewicza ${ }^{30}$, nie możesz mi powtórzyć? Ośmielony łagodnością Profesora, cały powiedziałem jak najwyraźniej i najdobitniej i uważałem, że cała klasa $\mathrm{z}$ uwagą mnie słuchała a Profesor po ukończeniu pogłaskał mnie i uścisnął. Masz dobrą pamięć i przytomność umysłu, widać, że masz godnych rodziców, którzy cię od czci należnej Bogu doskonalić zaczęli. Nie zrażaj się innymi naukami o których stopniowo dowiadywać się i uczyć będziesz, a sprawisz przyjemność rodzicom i nauczycielom, którzy tobą zajmować się będą. Uczyliż ciebie po łacinie? - nie znam co by to było takiego. Jest to język w którym Katolicy Rzymianie po większej części chwalą Pana Boga, który używany jest w potrzebach i stosunkach obywatelskich, a co najwięcej że wiele w nim jest napisanych rzeczy, które człowiek uczący się znać powinien. Zdziwiony taką rozmową, ośmieliłem się powiedzieć, że to wszystko być musi, ale dlaczegoż to ma być w obcym języku, kiedy i nasz polski język wyraźnie rzeczy tłumaczy. Zaśmiał się Profesor - to jest moje dziecko nad twoje siły, później i sam się o tym przekonasz, a teraz umieszczam cię w infimie (pierwsza klasa), żebyś poznał porządek i to wszystko czego się masz uczyć. Skłoniłem się na to zalecenie i prosiłem, aby mnie bez wyłączenia wszystkiego uczono; jakoż kazano mi abym się postarał o Donata ${ }^{31}$ i Alwar $^{32}$. Na następną lekcję już one miałem i pierwszą moją lekcję zacząłem od wokabuł, które dla podobnego zakończenia (Bóg Deus, mój meus), tak mię bawiły, iż zawsze w dwójnasób umiałem co mi naznaczono: a gdy z kolei wdrożyłem się w Alwar i po niejakim czasie przeszedłem deklinacje i koniugacje, zacząłem się uczyć praeterita et genera ${ }^{33}$ jak mi powiadali kandowanym czyli śpiewnym wierszem, to mnie jeszcze bardziej bawiło, że zaś pamięć i objęcie z łaski Pana Boga miałem dobre, szło mi łacno i nieraz ubolewałem nad tymi, którzy tej łatwości nie mieli, gdy zaś myśl tych wierszy wyrozumiałem bawiło mnie to niezmiernie i nie czując żadnej przykrości uczenia się, przechodziłem corocznie z jednej klasy do drugiej. Gdym już nawykł do Alwara, że i w potocznej mówie często różne komiczne z tego względu wiersze cytowałem,

${ }^{30} \mathrm{~W}$ istoçie jest to utwór S. Gessnera w przekładzie na język polski A.Naruszewicza (Zabawy przyjemne i pożyteczne, 1771).

${ }^{31}$ Aelius Donatus, żyjący ok. poł. IV w., autor gramatyki lać. dla początkujących - Ars minor, w której w formie pytań i odpowiedzi omówione były części mowy, oraz obszerniejszego podręcznika dla zaawansowanych - Ars maior. Oba podręczniki zyskały ogromne uznanie i popularność i w średniowieczu były powszechnie stosowane w szkołach. W czasach późniejszych Donatus oznaczało po prostu podręcznik gramatyki.

${ }_{32}$ Jezuita Emanuel Alvarus (Alvarez, 1526 -1582), był autorem podręcznika gramatyki łacińskiej Institutio grammatica, który zdobył ogromną popularność w całej Europie. W Polsce wydany został już w 1577 r. (w Poznaniu). Na gramatykę dla początkujących w nauce podręcznik ten się nie nadawal, pomimo rozmaitych wierszyków mnemotechnicznych przy pomocy których autor usiłował ułatwić zapamiętanie ogromnej ilości reguł i wyjątków, stąd cały szereg adaptacji i przeróbek - wszystkie nazywano Alvarami. Tu może chodzić o wydane w Wilnie w 1793 r., De institutione grammatica libri tres. Editio nova correctior, lub inne podobne.

3.3 praeterita et genera (łać.) - czasy przeszłe i rodzaje. 
mocno uderzony byłem przemianą Alawara na Pijarską Gramatykę $e^{i 4}$, z przyczyny jakoby ta była jaśniejszą i do pojęcia młodych więcej dostosowana, lecz i Pijarska Gramatyka długo nie trwała, kazano bowiem uczyć Gramatyki Kopczyńskiego ${ }^{35}$, a to na tej zasadzie, iż nabywają się wiadomości drogą najkrótszą, kiedy się przechodzi drogą porównania i rozbioru.

W tym chaosie przemian, gdy wraz jedne książki zamieniały się na drugie, nasłuchałem się, nie mając jeszcze własnego zdania, różnych obcych. Starzy Profesorowie utrzymywali, że to jest rzecz niepotrzebna, inni rozważniejsi zawieszali swoje zdanie, a nowo przybyli obstawali za ostatnimi. Ja wahałem się z moim przekonaniem, póki ostatni cios nie był zadany starej metodzie uczenia i nie skasowano całkowicie zakładów edukacyjnych ex jezuickich, a wtenczas musieliśmy się udać do szkoły XX Bazylianów nowo założonej. Było to w Brześciu Lit. 1800 roku $^{36}$.

Nowi energiczni nauczyciele wprowadzili inny porządek, inne nauki i odmienny ich sposób uczenia się. $Z$ początku przywykłym polegać na samej powadze Profesora (ipse dixit) ${ }^{37}$ dziwnie wydawała się ta poufałość naukowa, dla której wolno było w każdym razie i czasie uczniom zapytywać się, dla czego to? lub jak to? Ale gdy stopniowo przekonaliśmy się, że droga rozbioru i rezonowania najskuteczniej rozwija władze umysłowe i ułatwia nabycie nauki, otworzyły się nam oczy, żeśmy podług starej metody wiele czasu stracili na ćwiczenie samej pamięci, mało użytecznymi erudycjami i nieodżałowana była szkoda, żeśmy tak od początków nie zaczęli.

Fałszywe przeto jest przekonanie, aby nauczyciele w niższych klasach mieli być przydatni bez wyboru; owszem oprócz nauki, sposób jakiego trzymać się mają przy zaszczepianiu pierwszych wiadomości i dojrzałego rozsądku dla obudzenia lub sprostowania władz umysłowych, domowym, niemetodycznym a czasem przeciwnym sposobem nadwerężonych. Taka na pozór łatwa znajomość nie jest czasem i przy największym nauczyciela usposobieniu dana: dostrzeżona zaś, warta wszelkich zobowiązań aby początkowym uczeniem młodzieży się zajęli - można umieć, ale umieć uczyć to podwójna wartość.

W nowym zawodzie nauk ukończywszy szkoły, powróciłem do domu i nieraz znajdowałem się w przykrym położeniu, kiedy odpowiadając na zadawane kwestie towarzyszów ojca mojego, godzić musiałem uszanowanie wiekowi ich należne, z pokazaniem niekiedy zupełnej ich niewiadomości. Zamilczam o innych przedmiotach, ale pomieścić się im w głowie nie mogło, aby rolnictwo wymagało uprzednich dość ważnych wiadomości naukowych, kiedy gumienny lub wójt, łatwo się układa na dobrego gospodarza. Zgadzali się wprawdzie, że zmieniły

${ }^{34}$ Wolski ma na myśli gramatykę ks. Stanisława Konarskiego, Grammatica in usum iuventutis scholarum Piarum - pierwsze wydanie w Warszawie w 1741 r., a następnie blisko trzydzieści kolejnych (w Warszawie, Wilnie, Krakowie i Berdyczowie, gdzie w 1827 r. ukazało się ostanie juz wydanie tego dzieła). Od 1776 ukazywała się w wersji polskiej, Grammatyka tacińska pijarska. Zob. Marian Plezia, Dookoła reformy szkolnej St. Konarskiego (Studia klasyczne pijarów polskich). Lublin 1953.

35 Onufry Kopczyński (1735-1817), Gramatyka dla szkót narodowych na kl. I, Warszawa 1778; na kl.II, Warszawa $1780 ; n a k l .3$, Warszawa 1781 . Wszystkie trzy części gramatyki Kopczyńskiego miały w latach następnych wiele wydań w Warszawie, Wilnie, Krakowie, aż do r. 1839.

${ }^{36}$ Powiatowa szkoła szlachecka w Brześciu Litewskim, prowadzona była przez bazylianów od 1797 r., poprzednio funkcjonowało tam kolegium jezuickie (L. Zasztoft, Kresy 1832 -1864. Szkolnictwo na ziemiach litewskich i ruskich dawnej Rzeczypospolitej,S Warszawa 1997, s. 175-176).

${ }^{37}$ Ipse dixit (łać.) - on sam powiedział - w ten sposób według Cycerona (De natura deorum I,5,10), uczniowie i następcy Pitagorasa uzasadniali swoją naukę, powołując się na autorytet mistrza. 
się czasy, cena zboża niska, za granicę nie potrzebują - tymczasem potrzeby się zwiększają i niedostatek pieniędzy coraz jest większy.

Gdy na mnie kolej mówienia przyszła, odezwałem się: póki potrzeby ograniczone były i zagraniczne narody potrzebowały naszego zboża, stan jakkolwiek lichy gospodarstwa naszego, mając zbytek zboża, mógł korzystnie sprzedawać za granicę i gotowy grosz do kraju sprowadzać, lecz za zmianą stosunków i okoliczności, zagraniczni mieszkańcy zajęli się usiłowaniem aby małą swoją rozległość gruntów, powiększyć urodzajnością i tego dokazali za pomocą nauk, które pożywność roślin i uprawę gruntów wyświeciły. Jeżeli jeszcze do tego dodamy, że rachunkowe nauki pomnożyły machiny, którymi się praca ułatwia, nie dziw że zaprzestano kupować zboże i pozbawiono naszych rolników dochodu jaki ich oczekiwał. Więc i my idźmy tąż samą drogą, to jest starajmy się pomnożyć plony aby ich taniość wynagrodziła się ilością i surowy ten materiał przemysłowym sposobem obracajmy na inny, któryby na miejscu spożyty lub pokupniejszy został. Jeżeli zaś opatrzymy się w machiny ułatwiające pracę i zaprowadzimy manufaktury, aby się obejść bez zagranicznych wyrobów; stan rolniczy a następnie wszystkie inne się ulepszą.

$\mathrm{Z}$ rezonowania pana młodego, odezwał się jeden $\mathrm{z}$ towarzyszów, widać że nas wszystkich chciałby do szkół wyprawić - bynajmniej, to tylko powiadam, że człowiek całe życie uczyć się i doskonalić się może, kiedy korzysta z odkryć i postrzeżeń i bez uprzedzenia o nich sądzi należycie. Może Opatrzność dozwoli mi korzystać z tych szczęśliwych pomysłów i odkryć, jakie olbrzymim krokiem w naszych czasach powstają w rozmaitych gałęziach naukowych, wtenczas dostatecznie się objaśnię, dopiero zaś przestaję na tym wyznaniu, że czuję tego jak największą potrzebę.

Wiek dojrzały. W epoce kiedy uniwersytety staraniem rządu ustalać się i reformować poczęły, zajęty myślą dalszego doskonalenia się postanowiłem dom opuścić. Ojciec zgodziwszy się na to przykazał pod błogosławieństwem, abym ucząc się światowych nauk nie zapominał o czci należnej Bogu i nabywaniu cnót towarzyskich, bez czego człowiekiem uczciwym być nie można. Przejęty jego uwagami, czule za to podziękowałem a otrzymawszy rodzicielskie uściśnienie udałem się do Uniwersytetu Wileńskiego 1803 r. Z początku przysłuchiwałem się rozmaitym kursom naukowym, dla wypróbowania siebie, do czego mógłbym mieć więcej zdolności i powołania, bo wszystko było dobre, wszystko pożyteczne. Postanowiłem na koniec aby nauki przyrodzone i scjentyficzne obrać za przedmiot główny, bo w nich najwięcej zajęcia się umysłowego i zastosowania na potrzeby ludzkie, a inne obrać tylko za dodatkowe.

Czy z własnej woli, czy zmuszeni okolicznościami zajmujemy miejsce, powinniśmy obowiązki stanu`spełniać należycie, od tego bowiem zależy szacunek, o jaki każdy starać się powinien i załatwienie potrzeb społeczności. Prócz tego zaprzeć się nie możemy, że wewnętrzny świadek czyli sumienie zradza wtenczas tylko prawdziwą pociechę i sprawuje pokój duszy, jeżeli szczerze i stosownie do sił i zdolności pełnimy to do czegośmy się zobowiązali.

Wątpliwości nie ulega, że dobro ogólne składa się ze szczególnych usiłowań wielu osób, a lubo dopięcie tego celu zawsze połączone jest z wielu trudnościami, dla rozmaitych zdań, usposobień, pomysłów i różnego widzenia tejże samej rzeczy, dziwić się nie należy, że zradzają się stąd nieporozumienia, przeciwności, nieukontentowania, a czasem prześladowanie i ucisk. Dla uniknięcia tego, nieodzowna jest potrzeba rządzić się roztropnością, która jest jakby wypadkiem pogadzania usposobień nawet naukowych, ze szczegółami nieodłącznymi od życia towarzyskiego i ten przymiot duszy powinien przewodniczyć wszystkim przedsięwzięciom, pomysłom, czynom i działaniom chociażby z własną zdania naszego lub osoby ofiarą. 
Nauki kształcą serce i rozum. Ukształcenie serca robi człowieka moralnym i takim każdy ze społeczności być powinien. Ukształcenie rozumu czyni człowieka więcej pożytecznym, a że nabycie jego zupełne prawie jest niepodobnym, dla licznych nauk które go tworzą - dlatego i uczonych są wydziały i społeczność musi się składać z rozmaitych stanów ludzi, a każdy $\mathrm{z}$ nich doskonali się w tych tylko naukach, jakie bliżej jego powołaniu i potrzebie odpowiadają.

$\mathrm{Na}$ tej zasadzie po większej części są urządzone szkoły publiczne, to jest: początkowe ograniczają się zaszczepieniem zasad religijnych, cnót domowych i towarzyskich, czyli kształcą serca; wyższe zaczynają rozwijać władze umysłowe do pojęć rozumowi ludzkiemu przystępnych i przygotowywać do słuchania nauk w całej rozciągłości, z których jedne przez rozważanie dzieł Stwórcy uzacniają człowieka, inne przez swoje zastosowania nieprzeliczone w społeczności sprawują pożytki.

Takie zalety publicznego wychowania nadają im pierwszeństwo przed innymi, a gdy się dołączy ta uwaga, że z jednostajnego sposobu kształcenia się i wychowania zradzają się jedność i zgodność obywatelska i krajowa, nieocenione stąd dla ogółu wynikają korzyści.

Pomnożone zakłady naukowe, lubo niemylnie przykładają się do zaprowadzenia oświaty, chcąc jednak uczynić ją powszechną i na wszystkich mieszkańców rozlewającą się, należy wesprzeć jak najliczniejszymi ogłoszeniami wiadomości naukowych. Nie wszyscy są w stanie korzystać z zaprowadzeń miejscowych, nie wszystkim potrzeby domowe i okoliczności dozwalają oddać się im na czas przydłuższy, ale każdy może znaleźć wolne chwile, aby zwrócić uwagę na rzeczy już gotowe, pracą i staraniem ludzi do tego usposobionych obrobione a w pismach łatwo nabyć się mogących zawarte. Pisma te tak powinny być stopniowane, jak idą stopnie rozmaitych stanów ludzi, którzy społeczność składają, a im są potrzebniejsze i użyteczniejsze, tym nabycie ich powinno być łatwiejsze. W moim przekonaniu cenzura rządowa dla przeszkodzenia aby zasad szkodliwych porządkowi towarzyskiemu nie zaprowadzać, jest potrzebna, ale krytyka erudycyjna pomnieć powinna na zdanie Kochanowskiego: niech jak kto może, dobru publicznemu pomoże $e^{38}$. W naszym wieku wszystko się przyda, co jest nacechowanym wiadomością naukową lub użytkiem. Czytujmy, uczmy i piszmy; kto czyta to się uczy; kto uczy, dwa razy się uczy; a możnaby dodać, że kto pisze, dwa razy uczy się i uczy.

Takim przekonaniem powodowany, po wysłuchaniu kursów uniwersyteckich w stopniu magistra filozofii, naznaczony zostałem roku 1807 na nauczyciela nauk przyrodzonych w gimnazjum guberni grodzieńskiej w Świsłoczy, a pełniąc obowiązki lat 25, gdy mi zdrowie słabnąć poczęło, przy wysłużeniu rangi radcy kolegialnego i znaku dwudziestopięcioletniej nieskazitelrej służby, korzystałem z łaski monarszej i zostałem emerytem.

W ciągu mego zawodu naukowego, czytałem, pisałem i rozmyślałem nie mało, a ślady mego zajęcia się, sformowały manuskrypt, który zebrawszy w jedno, mam zamiar złożyć po moim zgonie w jakim zbiorze naukowym, nie dlatego by m powiększył liczbę uczonych, bo tego sobie nie przyznaję, ale dla historii naukowego postępu; prócz tego spodziewam się że pomiędzy moimi pismami znajdą się takie myśli, które w późniejszych czasach rzeczywiście pomiędzy uczonymi się rozwinęły, a tymczasem wykażą stan nauk tego czasu w którym żyłem.

Rozpraw kilka z filozofii nauk przyrodzonych jako to: O czlowieku; O poczqtkowym nastaniu istot stworzonych; O snie i marzeniach sennych; O pokarmach i napojach rozmaitych lu-

${ }^{38}$ Dokłádnie: a jako kto może, niech ku pożytku dobra spólnego pomoże, J. Kochanowski, Pieśń XIX, w. 11-12. 
dów; Wiadomości meteorologiczne ${ }^{39}$, a mianowicie ${ }^{40}$ O spadku kamieni meteorycznych blisko Biategostoku we wsi Fastach roku 1827 d.27 września, są drukowane, albo oddzielnie albo w Pamiętnikach wileńskich, albo osobliwie w Magnetycznych w różnych datach; reszta rozpraw w czasie naukowych posiedzeń lub przy rozmyślaniu w wolnym czasie są w manuskrypcie. Powodując się zaś tą zasadą, że należy szanować porządek towarzyski - w moich wyrażeniach starałem się go nie naruszać; ale $\mathbf{z}$ drugiego względu, że rozporządzenia samego Boga, udzielone nam zostały władze umysłowe do rozważania dzieł jego; powodowałem się własnym przekonaniem, z którego sami za siebie przed tymże Bogiem zdamy sprawę.

Wygotowany jest także manuskrypt Fizyki, stosownie do wiadomości jakie w tymże czasie przy ograniczonych naukowych zasobach zebrać mogłem. Różny on jest od napisanej przeze mnie Fizyki wydrukowanej roku 1817 w Warszawie a zapewne nie godzi się z teraźniejszymi wiadomościami; bo to jest rodzaj nauki iż w miarę coraz dalszego zgłębiania dzieł Stwórcy, przyjmować potrzeba i inne zasady.

Pisałem w Białymstoku roku 1847

$$
\text { (-) Jan Wolski }
$$

\footnotetext{
${ }^{39}$ Dwóch poprzednich tytułów nie udało się odszukać, tu Wolski ma zapewne na myśli: Wypis z Dziennika dostrzeżeń meteorologicznych przy Gimnazjum Gubernii Grodzieńskiej w Świstoczy, „Pamiętnik Magnetyczny Wileński”, t. 1 (1816), s. 36 - 38; może też chodzić tu o jakiś niezidentyfikowany artykuf. Nie jest jasne, czy niepodpisany artykuł: Zapis meteorologiczny, „Dziennik Wileński”, t. 1815 s. 292-295, jest autorstwa Wolskiego - tak zdaje się wynikać z przypisu do poprzedniego artykułu: to postrzeżenie uwazać się może za dalszy ciąg zpisu meteorologicznego pomieszczonego w 1 tomie Dziennika Wileń. Wydaje się jednak, że w maju 1815 r. kiedy w Wilnie spadł gwałtowny grad w tym artykuliku opisany, Wolski przebywal w Świsłoczy, a przypis tu cytowany, może pochodzić od redakcji „Pamiętnika Magnetycznego".

4h Mianowicie - tu w znaczeniu: zwlaszcza, szczególnie.
} 